\title{
Pollution of the Highways Runoff
}

D. Beránková* \& H. Brtníková \& J. Kupec

T.G.Masaryk Water Research Institute, p.r.i.

*Corresponding author: danuse_berankova@vuv.cz

P. Prax

Technical University of Brno, Faculty of building

J. Huzlík

Transport Research Centre

ABSTRACT: This paper collates the final results of the project dealing with the quantity and quality of highways rainfall - runoff. Field investigation was carried out through the period 2005 - 2007 on several stretches of D1 highway Praha - Brno. Low contents of the EU priority dangerous substances in surface runoff, which depends on the character of sampling and level of traffic intensity, were found. An impact on the water ecosystem, mainly on the algae Scenedesmus quadricauda, was confirmed through ecotoxicity testing. The measurement of precipitation and outflow has also brought findings about the variability of runoff coefficient in this built up transport area.

KEY WORDS: Highways, runoff, water quality, PAH, heavy metals, ecotoxicity.

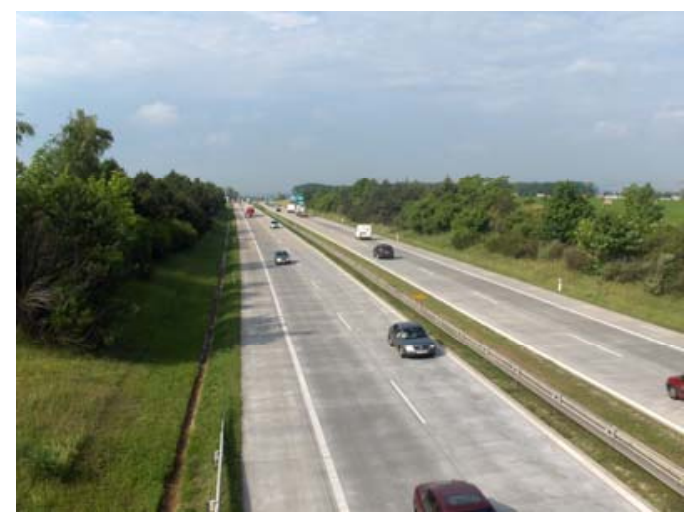

\section{INTRODUCTION}

In this section the results of the project $\mathrm{VaV} 1 \mathrm{~F} 54 \mathrm{G} / 011 / 120$ "Influence of highways and motorways on rainfall-runoff relations and their impact on water bodies pursuant to Directive 2000/60/EC" are given. The project was supported by Czech Ministry of Transport and dealt with quality and quantity of water flowing off from highways. The basic questions were defined as: What is the impact of highways and motorways on the receiving bodies and water 
bodies? Which are the main pollutants? In what quantities do the priority dangerous substances specified by EU occur? What are the recommendations and proposals for measures?

\section{GENERAL}

Pollution of the basic components of the environment (air, soil, water) caused by car traffic is very topical in the CR. The main causes are an ever growing density of traffic in cities and on motorways and highways, but also the further development of transport infrastructure and hundreds of kilometers of new highways which are being built.

Transport emissions with dangerous substances have a negative impact not only on the environment but also on human health. The intensity of pollution is connected mainly with traffic density, amount and composition of fuel and on the type of road. The type and condition of an engine and regime of driving are also important.

Many of emitted pollutants, e.g. polyaromatic hydrocarbons, cadmium, lead, mercury, nickel, are grouped in the catagory of priority dangerous substances specified by EU. The EU member states have a duty to eliminate their occurrence in the water ecosystem.

The main transport processes of this pollution in the environment are atmospheric dispersion; wash out from the road surface and splashing of small dispersion. It concerns mainly metals such as $\mathrm{Pb}, \mathrm{Cd}, \mathrm{Hg}, \mathrm{As}, \mathrm{Ni}$ and other toxic metals and their compounds, carcinogenic and mutagenic $\mathrm{PAH}$, but also benzene, persistent organic pollutants, dioxins, nitrogen oxide, etc., carbon oxide, particulate matters smaller than 10 or 2,5 micrometers.

The other type of emission is caused by asphalt and tire abrasion, corrosion and leakage of liquids from cars, dumped waste and numerous car accidents also contribute to pollution.

Use of de-icing chemicals in providing safe driving conditions during the winter months causes specific water quality problems, mainly high chloride content and an increasing dissolved (toxic) fraction of metal. During snowmelt and rainfall periods it comes to the outflow of suspended solids with accumulated pollutants. Suspended solids are accumulated gradually in the drains and also in receiving water.

\section{METHODS}

Monitoring was performed in the period of 2005 - 2007 on the highways D1 Praha-Brno between 61.5 and $81.5 \mathrm{~km}$. Intensity of transport on this stretch is approximately 40 thousand cars/24 hours. Water quality was monitored on the inflow to the storm water sediment basins (SWSB) and in adjacent recipient. Also samples of snow and sludge on the bottom of these basins were analysed. The second monitored profile with the same density of traffic with automatic sampling was situated on the highway bridge on the 149.5 kilometer of D1. The third monitored area was the new stretch at 233.0 kilometer of highway D1 with a very low intensity, and which has been operating only for a short period.

In the samples of water and leach of settled sludge basic chemical parameters, priority substances, etc., were analysed, and also ecotoxicity testing was carried out. The water samples were collected and analyzed according to the standard operation procedures for the sampling and analysis of water - Technical standard of water management and ISO/EN standards. 


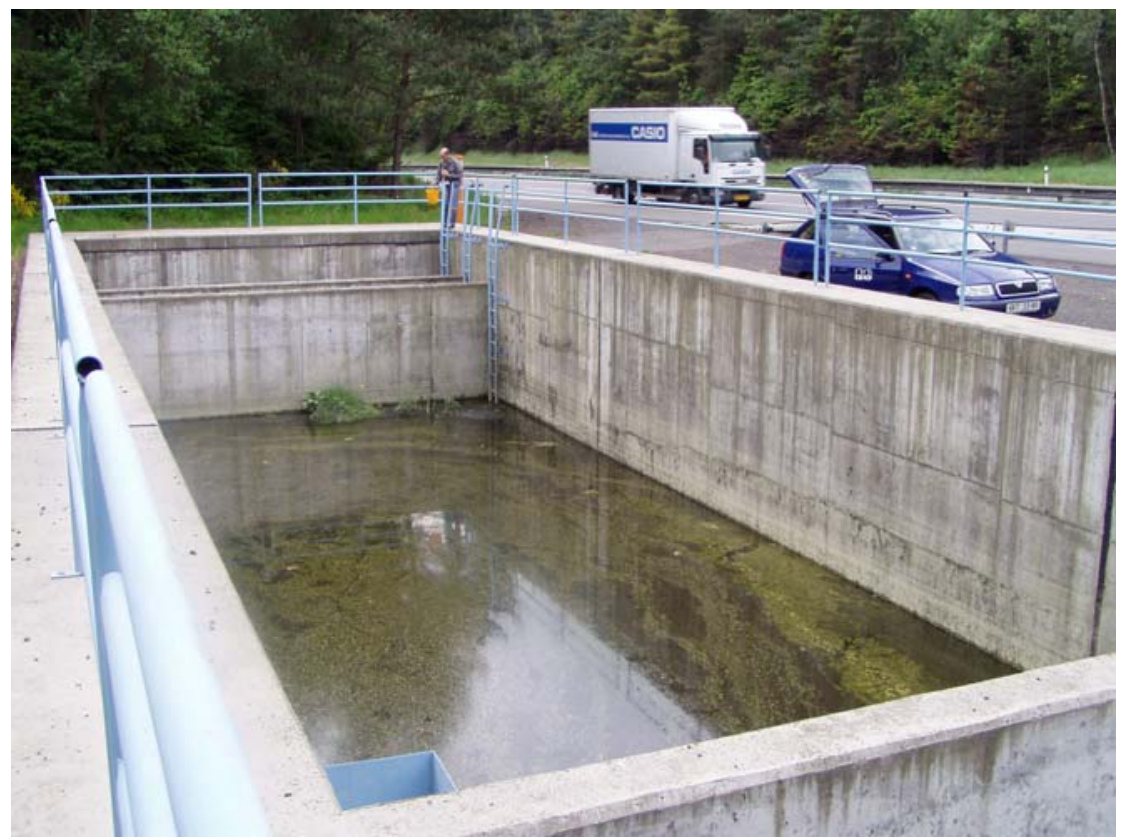

Figure 1: Profile on the storm water sediment basins (SWSB) on $61.5 \mathrm{~km}$ of D1

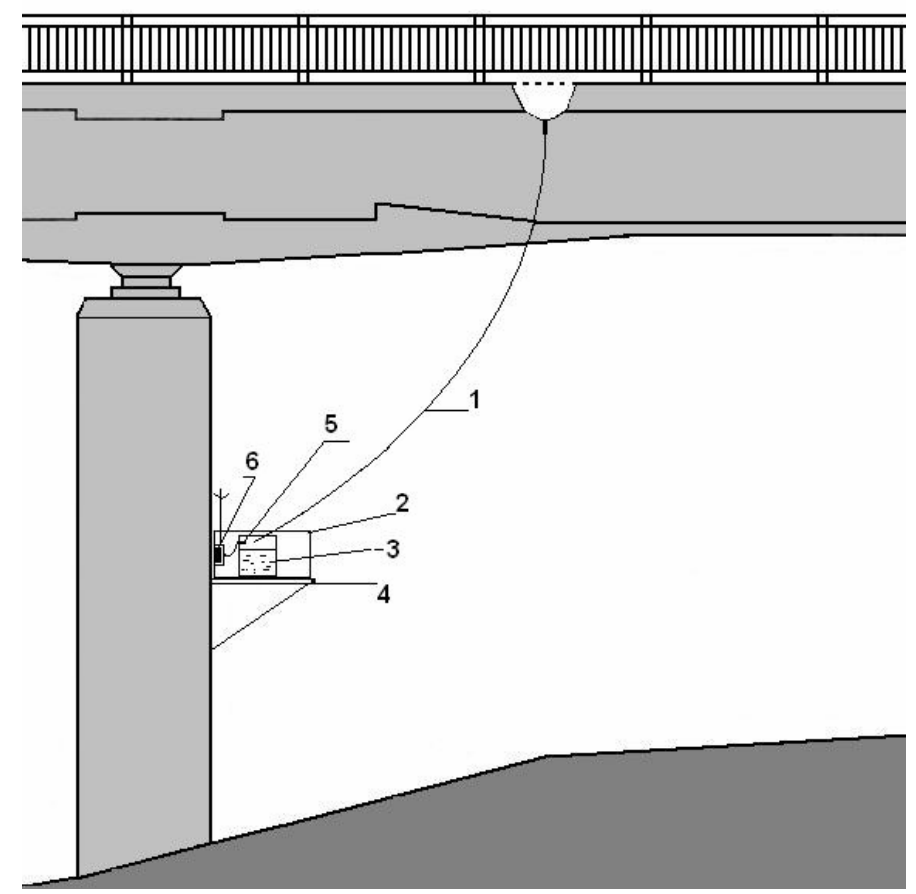

\section{Figure 2: $\quad$ Localization and scheme of an automatic sampling device}

Explanation: 1 tube, 2 plastic container, 3 sampling vessel, 4 consoles 5 water level contact maker, 6 transmitting program unit 


\section{RESULTS OF WATER QUALITY}

In Table 1 the results of realized measurement (stretch $61.5-81.5 \mathrm{~km}$ of D1) and a comparison with the limits of Regulation of. Gov. 229/2007 and Working qualitative limits (2005) are presented. The limits were used in the Czech Republic for period of characterization of water bodies. This process is a part of the implementation of Regulation 60/2000 EC (Water framework Directive - WFD) and preparation of River Basin Plans.

Table 1: $\quad$ Parameters of water quality of highways runoff

\begin{tabular}{|c|c|c|c|c|c|c|}
\hline Parameter & Unit & Average & Median & Q90 & $\begin{array}{l}\text { Reg. } \\
229 / \\
2007 \\
\end{array}$ & $\begin{array}{l}\text { Qualitative } \\
\text { limits } \\
(2005)\end{array}$ \\
\hline $\mathrm{Pb}$ & $\mu \mathrm{g} . .^{-1}$ & 3,82 & 2,40 & 6,10 & 14,4 & 5 \\
\hline $\mathrm{Cd}$ & $\mu \mathrm{g} .1^{-1}$ & 0,406 & 0,190 & 0,770 & 0,7 & 0,2 \\
\hline $\mathrm{Ni}$ & $\mu \mathrm{g} .1^{-1}$ & 45,3 & 21,8 & 132 & 40 & 5 \\
\hline $\mathrm{Hg}$ & $\mu \mathrm{g} .1^{-1}$ & 0,199 & 0,140 & 0,270 & 0,1 & 0,1 \\
\hline $\mathrm{Cr}$ & $\mu \mathrm{g} . .^{-1}$ & 4,83 & 4,50 & 6,80 & 35 & 2 \\
\hline $\mathrm{Cu}$ & $\mu \mathrm{g} .1^{-1}$ & 19,0 & 13,7 & 52,8 & 25 & 2 \\
\hline $\mathrm{Zn}$ & $\mu \mathrm{g} .1^{-1}$ & 142 & 69,0 & 400 & 160 & 10 \\
\hline $\mathrm{Cl}$ & $\mathrm{mg} .1^{-1}$ & 1095 & 726 & 1510 & 250 & - \\
\hline Hydrocarbons C10-C40 & $\mathrm{mg} . \mathrm{l}^{-1}$ & 0,145 & 0,145 & $\mathbf{0 , 8 8}$ & 0,1 & - \\
\hline Benzo(b)fluoranthene & ng. $1^{-1}$ & 7,66 & 3,75 & 20,4 & 60 & 30 \\
\hline Benzo(k)fluoranthene & ng. $1^{-1}$ & 5,87 & 3,65 & 15,7 & 60 & 30 \\
\hline Benzo(a)pyrene & ng. $1^{-1}$ & 5,63 & 2,10 & 11,8 & 100 & 50 \\
\hline Benzo(g,h,i)perylene & ng. $1^{-1}$ & 6,29 & 3,33 & 13,1 & 30 & 16 \\
\hline Indeno(1,2,3-cd)pyrene & ng. $1^{-1}$ & 5,69 & 3,25 & 15,5 & 30 & 16 \\
\hline Fluoranthene & ng. $1^{-1}$ & 21,2 & 9,80 & 63,0 & 200 & 90 \\
\hline$\Sigma 6 \mathrm{PAH}$ & ng. $1^{-1}$ & 7,66 & 3,75 & 20,4 & 200 & - \\
\hline
\end{tabular}

Q90 - value of $90 \%$ of exceeding

It is possible to say that the highest concentrations in runoff were found in the samples from the automatic sampler. Other waters probably dilute other samples of water from the rainfall edimentation basins.

Almost high-risk pollution levels were found in the samples of settled sludge as a consequence of accumulation and fixation of organic compounds and metals to particulates. In Figure 3 the results of the concentrations of phenanthrene, pyrene, fluoranthene and fluorene can be seen from all monitored profiles including sampler. 


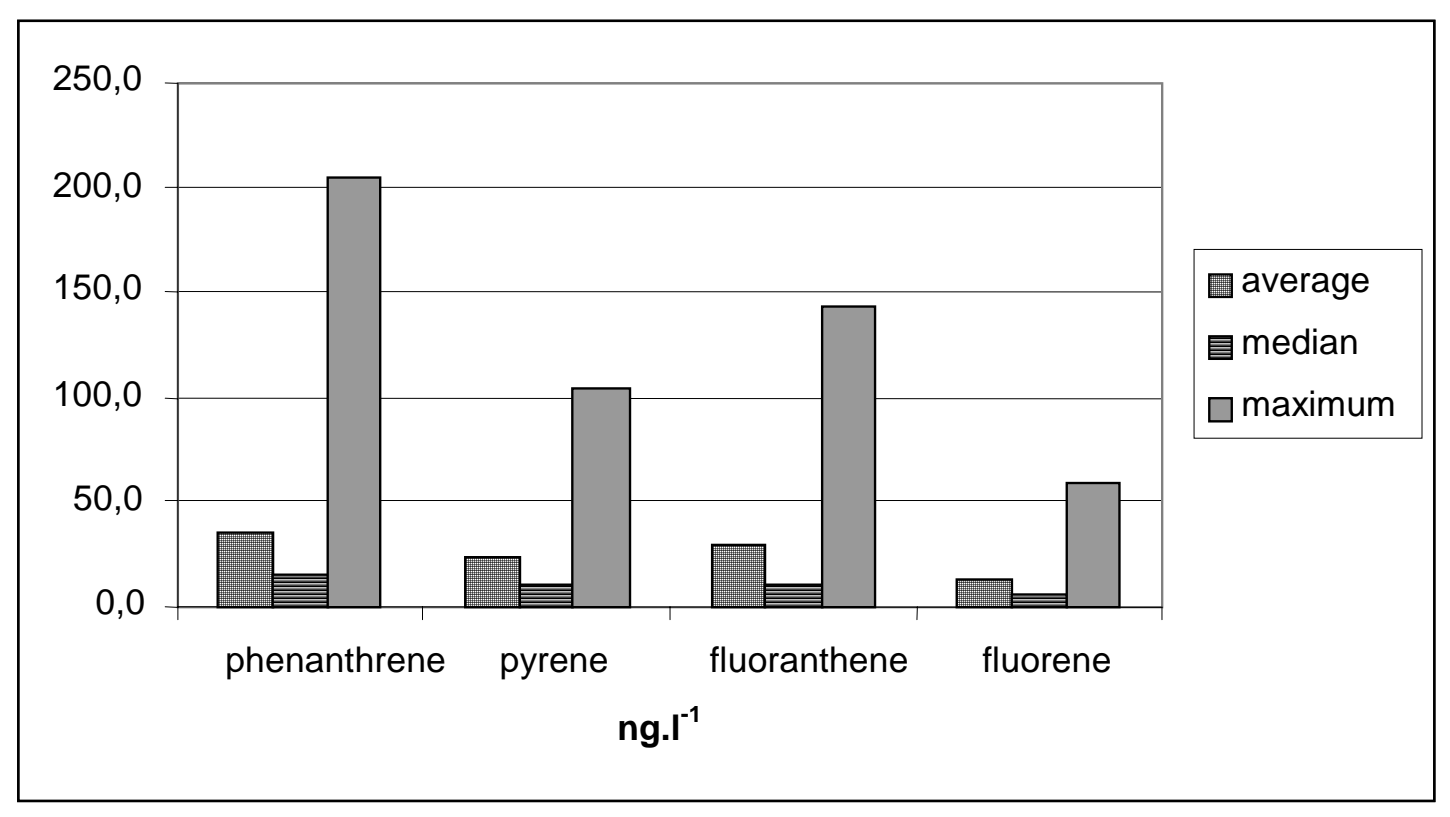

Figure 3: $\quad$ Results of contents of PAHs in highways runoff

Results of ecotoxicity testing has confirmed that acute toxicity is positive, mainly by testing algae Scenedesmus quadricauda, in comparison with the testing on invertebrate Daphnia magna, and is connected also with higher concentration of chloride in water.

\section{RAINFALL - RUNOFF CONDITION}

The measurement and evaluation of rainfall-runoff condition was carried out on the object storm water sediment basins (SWSB) on $72.1 \mathrm{~km}$ of highway D1 Praha-Brno with the 5,375 ha of dewatering area. The course of rainfall events was registered by a self-recording gauge. Inflow and outflow from basin were measured by Poncelet and Parshal devices. Data were registered and communicated. In the next picture the rainfall events and also the response in the catchments area are shown.

For rainfall cases the average outflow coefficients were $(0.53-0.87)$, showing a share between outflow volume and rainfall derived. Consequently a specific surface runoff was calculated, on the unit of highways dewatering area. The value was used for the mathematical modelling of load and concentration of chloride in two recipients. 


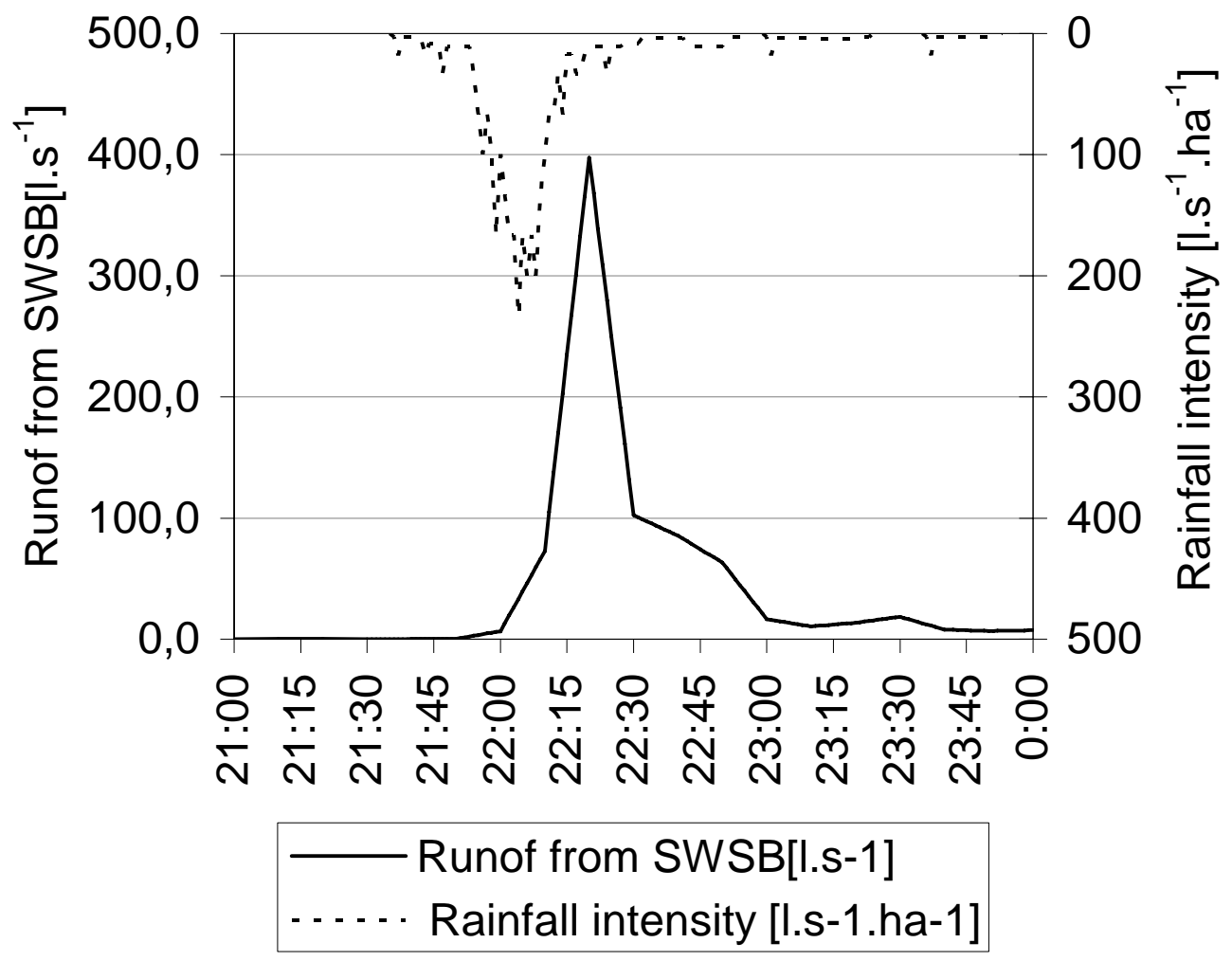

Figure 4: $\quad$ Response in the catchments - rainfall - outflow 12.9. 2005

\section{POTENTIALLY THREATENED WATER BODIES}

One of the outcomes of this project was the selection and assessment of potentially threatened water bodies by run-off waters from the highways in Czech Republic. For this model, analysis tools of spatial analysis of Geographic information systems (GIS) and multi-criterion assessment were used. Selected factors entering the analysis are represented by polygons (climatic conditions - long term precipitation amount, altitude, soil conditions, protective zone of water resources, protected area of natural water accumulations), poly-lines (highway trace through water body, traffic intensity) or points (crossing of water body with highway). The result of this analysis is shown in Figure 5.

This method of assessment is important for the first identification of the areas by using a similar criterion and a specific simplification for them. The recommendations and proposals of protective measures will be elaborated for selected areas with high potential threat. 


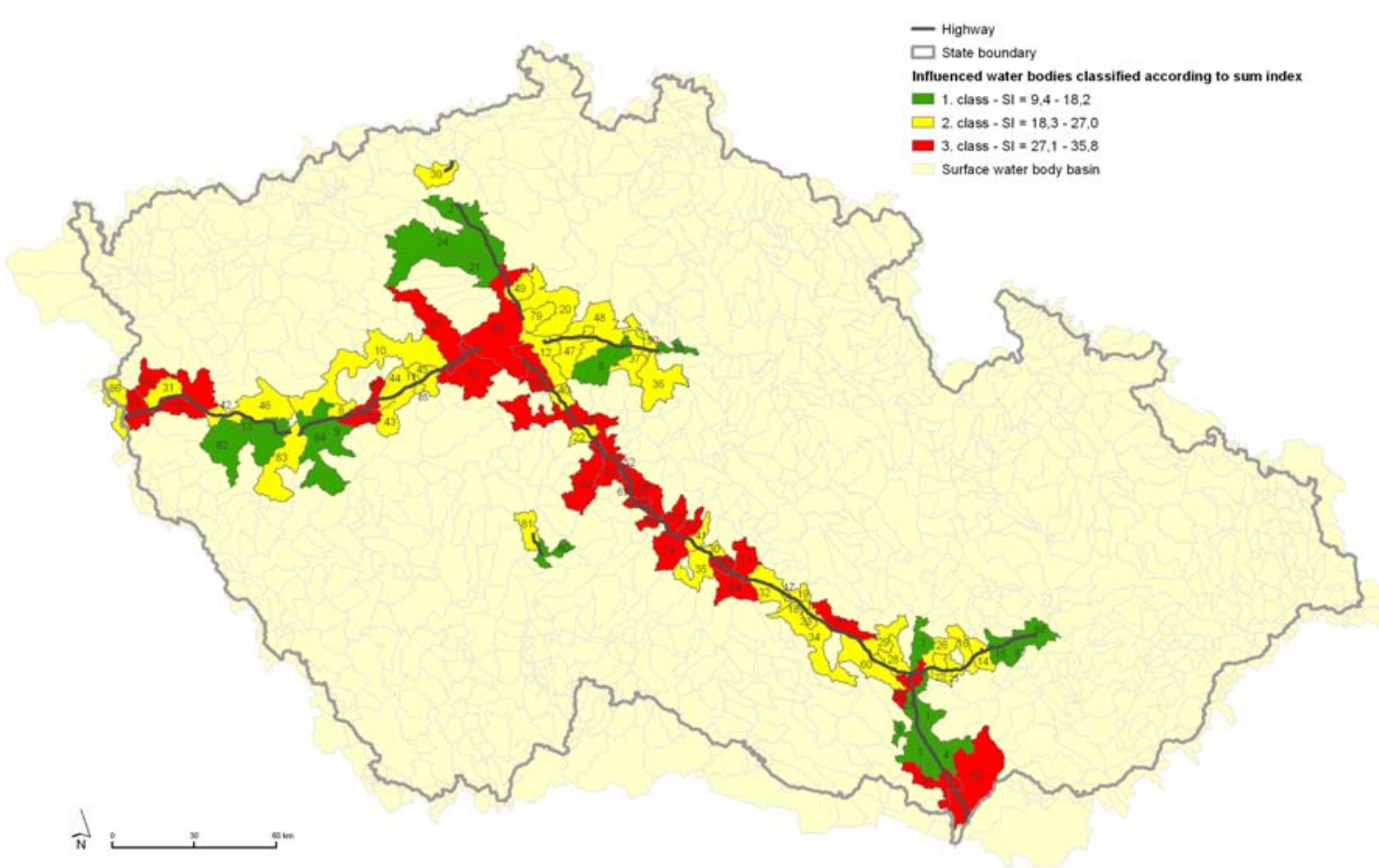

Figure 5: Potentially threatened surface water body basins

\section{MEASURES AGAINST CONTAMINATION}

Implementing some measure against the discussed contamination is known abroad: Best Management Practices (carrying out periodic maintenance, determination of limits and system of control - BMP). In Germany and other European states there are various systems of secondary treatment of water with infiltration of the out flowing rainfall runoff. The newest type is 3-stages equipment with a soil filter and consequential soil infiltration or draining away into receiving water.

\section{CONCLUSION}

The findings from this project can be summarized as follows:

The negative impact of runoff from highways on the recipients and water bodies also enhances a certain amount of priority dangerous substance as specified by EU.

High concentrations of chloride from winter road maintenance increase ecotoxicity of water, which was demonstrated by testing on algae.

During intensive rainfall small receiving bodies flood; polluted suspended solids are diluted and transported into the river basin. 
Similarly, as in other European states, it seems to be necessary to monitor and control this potential strain of pollution along the highways and to do the BMPs and to project and implement protective measures against it.

\section{ACKNOWLEDGEMENT}

The research described in this presentation has been sponsored in $2005-2007$ by the Project VaV 1F54G/011/120 „Vliv srážkoodtokových poměrů dálnic a rychlostních komunikací a jejich dopad na vodní útvary ve smyslu Směrnice 2000/60/ES“.

\section{REFERENCES}

Adamec, V., et. al., 2006. Výzkum zátěže životniho prostředí z dopravy. (Závěrečná zpráva projektu VaV CE 801/210/109). Brno: CDV, 86 pp.

Beránková, D., et. al. 2007. Vliv srážkoodtokových poměrů dálnic a rychlostních komunikací a jejich dopad na vodni útvary ve smyslu Směrnice 2000/60/ES. Periodická roční zpráva projektu VaV 1F54G/011/120. Brno: VÚV T.G.M. 60 pp. 